\title{
THE CONTRIBUTION OF MOBILE MONEY SERVICES ON SMES INTERNATIONALIZATION IN TANZANIA: A CASE OF EPZA
}

\author{
Nkupama Philip Conwell ${ }^{1}$ and Vicent Stanslaus ${ }^{2}$ \\ ${ }^{1}$ Planning \& Commercial Operation Manager, Kariakoo Market Corporations \\ ${ }^{2}$ (BA-Economics, MIB, MSc Economics)-Assistant Lecturer, The Open University of Tanzania, Faculty of Business \\ Management, Department of Marketing and Entrepreneurship
}

\section{http://doi.org/10.35409/IJBMER.2020.3168}

\begin{abstract}
The objective of the study was to establish the contribution of Mobile money services to SMEs internationalization using EPZA as a case study. The study was conducted in Dar es Salaam. It covered Ilala, Kinondoni and Temeke municipals. The specific objectives of the study were to find out the extent to which financial services, features, cost saving, perceived security, and perceived convenience and reliability in the mobile money use relate to SMEs internationalization.

The analysis was done using SPSS (Statistical analysis software) through mean and standard deviation. A sample size of 145 SME actors and mobile money agents was randomly chosen to represent the population of the study. The five key informants were purposely chosen to give an in-depth view on the several questions.

The findings of the study revealed that financial services features, perceived cost saving, perceived security, and perceived convenience and reliability have a significant influence on Mobile money services and hence SMEs internationalization. However, among the four variables perceived convenience and reliability had strong influence than others. This study recommends that the government should cooperate with MNOs to build necessary infrastructures throughout the country so that MNOs can extend mobile money services even in rural areas. MNOs are advised to improve the micro business operators' use of the mobile payments and the digital technology by integrating the mobile money services with other operators outside Tanzania to allow the interoperability. They should also increase the transaction amount to facilitate SMEs transact larger amounts and enhance security measures
\end{abstract}

Keyword: Mobile money services, SME, SME internationalization.

\section{INTRODUCTION}

Internationalization of businesses and firms began with mankind's ability to travel across seas and borders. Scholars and academicians have tried to define internationalization on many occasions using many different perspectives and variables. In this study, SMEs internationalization is defined as firm-level behaviour that crosses national borders and can be 


\section{International Journal of Business Management and Economic Review}

Vol. 3, No. 02; 2020

ISSN: 2581-4664

evidenced at specific points in. (Kuivalainen, et al.,2012).

Nowadays, technological advancements, declining trade barriers and the like are driving the world economy to become more and more integrated and this rapid globalization has enabled SMEs to become international in a quicker yet effective manner. The use mobile money services therefore have emerged as a major means of transactions for business firms and SMEs.

It should be noted that an enterprise is considered to be any organized effort intended to return a profit or economic outcome through the provision of services or products to an outside group. Carland et al, (1983). Traditionally the operation of an enterprise requires the investment of capital and time in creating, expanding or improving the operations of a business (Meredith, 2001).

In recent years, the world has realized an interesting trend of growth in the number of people being included in the financial systems. An increasing body of evidence shows that appropriate financial services can help improve household welfare and spur small enterprise activities (Gray, 2005). In low and middle-income countries $25 \%$ to $50 \%$ of the economy is comprised of the informal sector, which mostly constitutes self-employed individuals with micro and small enterprises.(ILO, 2012).

A decade ago, mobile money for the unbanked did not exist in Africa. In fact, mobile phones had only started their penetration into the region. Remarkably, however, by 2011 over 60 million customers had availed themselves for mobile money subscription (Davidson and Penicaud, 2011); a picture of outstanding growth compared to other technologies and their adoption. There is also macroeconomic evidence to show that economies with deeper financial intermediation tend to grow faster and reduce income inequality, (Wishart, 2006). MMS usage will bring business competitiveness by changing industrial structure, giving SMEs the way to outperform their rivals and spawns whole new business operations (Mutalemwa \& Anthony, 2014; Baganzi \& Lau, 2017, Kalugendo et al 2018).

Mobile phones use flourished in recent years and they are professed to be devices that serve the individual that owns it, and are also recognized as a social artifact. Katz, (1999) Apart from the social uses, earlier studies by Leung and Wei (2000) indicate that utilitarian uses of the mobile phone are more frequent and instrumental motives are much stronger than social uses. Various types of business deals including cross country transactions are being conducted on mobile phones daily. The two fundamental attributes of the mobile phone which has led to its flourished usage are mobility and immediate access. However, De Gournay (2002) puts forward that mobility is unquestionably the most distinguished characteristic of the mobile phone. It is this characteristic which has extended its usage from a traditional voice communication to other value added services like games, internet, banking, payments and informational services.

The report by the Tanzania Communication Regulation Authority (TCRA, 2013) indicates that by September 2012, a total of 56.7 billion Tanzania shillings were deposited through mobile money services, which would have not been transacted, or would have followed mainstream financial institutions. This overwhelming uptake might be attributed to subscriber preference for mobile money transfer because it is affordable and accessible to low income earners who form the bulk of the population.

An important consideration is the trend towards regulation of both mobile phones and mobile money services by the TCRA and the move by the government to introduce Excise Duty on 


\section{International Journal of Business Management and Economic Review}

Vol. 3, No. 02; 2020

ISSN: 2581-4664

mobile money services. These measures have an impact on subscription rates or the benefits that could be realized by SMEs. Even with these challenges, mobile money is a potential useful tool in poverty eradication through the provision of a secure, inexpensive way to transact (Must and Ludewig, 2010) well suited for SMEs that might have less access to financial services. SMEs in the EPZ involve manufacturing of products for exports and they export at least $80 \%$ of the product. For example, Tanzania is one the largest producers of cashew nuts in Africa. In 2011/2012, about $80 \%$ were exported and 20\% were locally consumed (Cashew nut Board, 2013 ) and in 2012/2013 about $89 \%$ were exported and $11 \%$ were locally consumed (Cashewnut board, 2013). Moreover, about $10 \%$ of cashew nuts were exported after being processed while 90\% were exported as raw nut (Cashew nut Board, 2013). An example of the company listed under EPZA is High Grade Cashew Ltd (Mbagala DSM). Therefore, the aim of this study was to find out the contribution of mobile money services in SMEs internationalization.

\section{EPZA Profile}

Export Processing Zones Authority (EPZA) is autonomous government agencies governed by a Board of Directors. The EPZ program in Tanzania was established in 2002 following the enactment of the Export Processing Zones Act. The scheme provides for the establishment of export oriented investments within the designated zones with the views of creating international competitiveness for export led economic growth. EPZA operates under the Ministry of Industry and Trade. EPZA is responsible for steering and implementing government policy on promotion of Special Economic Zones (SEZs) in Tanzania. Other functions of EPZA include the development of EPZ/SEZ infrastructure, provision of business services to EPZ/SEZ investors and issuing of EPZ/SEZ licenses. The authority functions as a one stop service center for all prospective and existing investors. Combined together, EPZA aims at enabling SME to export hence internationalize.

\section{Statement of the Problem}

Firms always strive to achieve growth and make more profits. One way of doing so is to expand the market for their products or services by going into international markets. The reasons for planning to internationalize are more likely the same to most of the firms (Mohibul and Fernandes, 2008). In general, SMEs internationalization can be understood as firm-level activity that crosses national borders, Wright and Ricks, (1994). SMEs internationalization is very important to SMEs in seeking for external markets, increasing the sales revenue and expanding the company image (Sun, 2004). SMEs internationalization is also very important for a country like Tanzania as they play a crucial role in employment creation and income generation. Indeed, SMEs development is closely associated with more equitable distribution of income and thus important as regards to poverty alleviation. At the same time, SMEs serves as a training ground for emerging entrepreneurs, (SMEs Development Policy, 2003).

Technological advancements and declining trade barriers are driving the world economy to become more and more integrated and this rapid globalization is enabling SMEs to become international, Dunning, (1981).

There are various reasons as to why SMEs are underperforming in internationalization; the main 


\section{International Journal of Business Management and Economic Review}

Vol. 3, No. 02; 2020

ISSN: 2581-4664

reason is resource scarcity (Westhead et al., 2002). Other causes include lack of knowledge on foreign language, cultural experience, poor knowledge of foreign market information, fear of foreign market risks, lack of capital, technical barriers, cumbersome export procedures, physical and technological infrastructure; banking and finance structure; legal and regulatory framework; marketing capabilities and associated linkages (Rutashobya and Jaensson, 2004).

SMEs have long been the engine of many economies in Sub-Saharan Africa as they play a pivotal role in sustaining growth for long term development (Sveinung et al., 2010). Failure of resolving a problem of SMEs internationalization will be of adverse effect to the economy at large. With the current technological progress, most SMEs face problems when entering the external market or marketing their products and services due to less use of mobile money services and online banking facilities which may lead to specific advantages and discovering niche markets (Buckley, 1993: (Pleitner et al., 1998).

In an effort to enable SMEs internationalize, the Tanzanian government has opened EPZA which help firms to export their products. Despite the efforts, most SMEs have not internationalized. This has led to more FDI inflow than FDI outflow and largely the imports are more than exports (Masum and Fernandez, 2008)

Mobile money services therefore may be used as a strategy for firms to internationalize (Hughes et al., 2008). This or any other strategy the firm may seek to apply should be based on resources to sustain the development of its international activities (Ahokangas, 1998). One device that has transformed the way people and businesses interact has been the mobile cellular phone. It has led to increased convenience while reducing communication costs, good security and easy access to credits realized mostly in Sub-Saharan Africa (Jack et al., 2010).

Mobile banking simply benefits the banks by drastically cutting down the overall expenses of offering financial services to consumers. Service providers and SMEs also benefit from mobile phone banking as it is regarded like the best way of achieving growth in terms of revenue (Gross et al., 2012). According to the World Bank, mobile money transfers have expanded to $16 \%$ of the total population in the Sub Sahara (Business Week Africa, 2012). This shows that studies should focus on the link between mobile money services and SMEs internationalization.

However, for the past few decades, researchers have been debating over existing theories and developing new theories of international business to explain why and how companies internationalize (Biggs, 2013). Internationalization theories explain different internationalization processes, which are taking place when companies expand and across national borders (Masum and Fernandez, 2008). Most studies in Tanzania and in the world have explained the link between mobile money services and SME growth, but few studies have explored the link between mobile money services and SME internationalization (Donner and Tellez, 2008; Ndiwalana and Popov 2008). In the developing world, where the reach of banking infrastructure is severely limited, this is a big deal, especially if one can reach more people faster and cheaper. Successful mobile money has the ability to enable and catalyze the development of mobile commerce (Herzberg, 2003; Hu, Li et al., 2008), particularly in the developing world. The downside is that current implementations tend to operate only within an MNO's network locking-in customers, and excluding other potential players in the sector (Ndiwalana and Popov, 2008). This study therefore, established the extent to which mobile money services influence 


\section{International Journal of Business Management and Economic Review}

Vol. 3, No. 02; 2020

ISSN: 2581-4664

SMEs internationalization.

\section{Objectives of the Study}

The research objectives include the general objective and the specific objectives. The main objective of the study was to establish whether or not the recent rapid growth of the use of mobile money services contributes to SMEs internationalization in the study area.

Specifically the study was conducted to establish the extent to which financial services features conducted through mobile money relate to SME internationalization, to determine the extent to which cost saving through mobile money use relates to SME internationalization, to determine the extent to which perceived security in the mobile money use relates to SMEs internationalization and to find out the extent to which perceived convenience and reliability through the use of mobile money services relate to SME internationalization.

It is important to explore usage rates of mobile money services, the nature of transactions, and their contribution to SME internationalization in Tanzania. The need to focus on affordable financial inclusion methods that contribute positively to facilitating SMEs with increased access to financial services through use of mobile money services to purchase the business products and supplies, and savings and loan accessibility hence internationalization is very significant. It is expected that the findings of this study will present valuable information to mobile phone companies that could develop or augment available products with special focus on SMEs. SMEs will also benefit from knowledge of financial services available through mobile money and how they can use them for internationalization. Recently, we have witnessed Vodacom Tanzania, one of the giant mobile operators, allowing its customers to access money transfer to Kenya through its network. This will definitely foster internationalization between SMEs of these countries. The study will contribute to the body of knowledge (education) relating to SMEs internationalization in Tanzania, especially on the part of the literature review. The study finding will help policy and decision makers to introduce better policies on how mobile money transactions can lead to SMEs internationalization.

\section{LITERATURE REVIEW}

\section{Theoretical perspectives}

This section reviews the various theories and school of thoughts which explains about Mobile Money services. The theories are presented in the context of general and specific theories. These theories were thought relevant to this study because they describe various means through which Mobile Money services can be provided to have an effect on SME internationalization.

\section{The Uppsala Model (U-Model)}

The Uppsala model is among the theoretical models that attempt to explain the internationalization process of firms. The theory which was developed by Johansson and (Vahlne, 1977) urges that firms start domestic operations and then use local agents to enter new markets, as sales grow, they replace local agents by opening up a subsidiary in a foreign market, and as growth continues they begin production in the host market (Hegge, 2002). The Uppsala or stage-theory model differs from other models and the reason for going global is that firms 


\section{International Journal of Business Management and Economic Review}

Vol. 3, No. 02; 2020

ISSN: 2581-4664

internationalize because other competitors in their national network internationalize as well what makes it dependents on each other. The Uppsala model considers internationalization as an incremental process of acquisition, integration and the use of knowledge about foreign markets. A basic theory of the Uppsala model is that lack of knowledge about foreign markets is a key issue to go international; however, this issue can be overcome via information about foreign market environments. The more data and awareness the firm has about a foreign market situation, the lower the perceived market risk will be and, thus, the higher the actual investment by the firm in that market supposes to be. The main concepts of the model are market commitment and knowledge, commitment decisions and recent business activities. According to Gronroos (2004), a technological solution or a physical resource that is geared to the needs and wishes of the user and that fits the situation in which it is to be used, may well enhance the quality of the service. It can improve the efficiency of operations and profitability as well. The use of mobile money services in conducting international transactions has simplified the exchange process and hence enabling SMEs to enter the international market. This fact brought in the gap for conducting this study. SMEs seeking to internationalize can use mobile money services technology. The U-model is therefore relevant to this study and it relates to the broader areas of knowledge being considered.

\section{The Born Global Theory}

According to the Born Global theory, many firms now do not develop in incremental stages with respect to their international activities. Firms are often reported to start international activities right from their birth, to enter very distant markets right away, to enter multiple countries at once and the likes. In general, a born global firm is referred to as a business organization that from its inception, seeks to derive significant competitive advantage from the use of resources and the sale of outputs in multiple countries (Oviatt and McDougall, 1994). The source of competitive advantage is often said to be related to a sophisticated knowledge base (Werawardena et al., 2007). These knowledge-intensive small firms perceive the world as one marketplace and start internationalizing from the outset. Born global firms may even enter domestic and foreign markets concurrently and expand into markets regardless of psychic distance (Bell et al, 2003). The Born Global theory is typically associated with the idea behind this study and brings in the gap for conducting a study of the contribution of mobile money services to SMEs internationalization. Crick and Spence (2005) argue that high-tech SMEs are more likely to internationalize by taking advantage of innovation and technology. The use of mobile money services as a means of facilitating financial transaction is a result of high-tech innovation which is likely to influence SMEs internationalization. Because born global firms are knowledgeintensive, they can better identify global niches and similarities across countries (Solberg 2002).

\section{Empirical literature review World Related Studies}

Empirical studies conducted by Gray (2005), World Bank (2012) and (GSMA, 2013) in SubSaharan Africa, shows that the momentum behind the take-up of mobile phones has raised the prospect for the provision of financial services via mobile phones. The studies also found out that this can have positive developmental consequences, including increasing the efficiency of payment systems and reducing reliance on cash as a transaction medium, thus broadening access 


\section{International Journal of Business Management and Economic Review}

Vol. 3, No. 02; 2020

ISSN: 2581-4664

to financial services. However the studies did not indicate how these benefits may lead to SMEs internationalization.

Must and Ludewig (2010) conducted a study on Mobile Money focusing on cell phone banking in developing countries. The study found out that Mobile Money allows users to pay for goods and services by using short message service (SMS) to transfer local currency or mobile minutes and time. Mobile Money can increase access of financial services. Unfortunately, regulatory and initial investment barriers have affected the widespread of Mobile Money. They also demonstrated that mobile money can serve as a poverty reduction tool by increasing savings rates, creating jobs, and increasing access to financial products offered by microfinance institutions. Based on the potential benefits of mobile money, they recommended that governments should subsidize the development of local Mobile Money infrastructure and adopt policies that enable the formation of a decentralized network. The study indicated the benefits of cell phone banking but its contribution to SMEs internationalization was not indicated.

Simiyu and Oloko (2015) conducted a study on Mobile Money transfer and the growth of small and medium sized enterprises in Kenya the case being Kisumu city in Kenya. The study established that mobile money had made a significant contribution to the SME sector. The majority of the traders rely on it as opposed to the formal banking sector for their day to day transactions. Thus, this study achieved its objectives and obtained detailed information arising from the use of mobile money services by SMEs. In respect to the conceptual framework, mobile money transactional costs, convenience and financial accessibility have all been shown to affect SMEs growth through the service leading to increased enrolment in mobile money services, increased financial transactions resulting in increased sales and therefore perceivable contribution to business growth. However this study did not explain how mobile money transfer can lead to SMEs internationalization.

Nyaga, (2014) conducted a study on the impact of mobile money services on the performance of small and medium enterprises in an urban town in Kenya;. The objectives of this study were, to investigate current awareness and uptake of various mobile money services, to determine if mobile money services uptake has any impact on SMEs growth through increased sales or savings and loan accessibility, establish if mobile money service qualities of low cost, convenience and accessibility lead to increased SMEs performance and establish if mobile money services are considered efficient and reliable by SMEs in Naivasha Town. The study found that mobile money has made a significant contribution to the SME sector. According to the findings majority of the traders rely on it as opposed to the formal banking sector for their day to day transactions. From the findings, it is evident that all the respondents in this study had a clear understanding of the basic functions of mobile money services. Mobile money services have a positive impact on sales. Efficiency and reliability contribute more to mobile money utility and SMEs growth. It is worth noting that the majority of the respondents had reservations on the convenience and cost of the service as a result of problems associated with the functionality of the service. Delays were a major concern of the respondents, but only a few people had experienced it. The study further found out that many of the players in the SME sector do not use the service for savings, to access loans or have bank accounts hence creating a major potential for mobile money. From the findings, it is evident that, mobile money users are not conversant with mobile-bank transactions on loan applications and repayment and prefer the normal banking system to mobile banking when it comes to loans. The study did not include the 


\section{International Journal of Business Management and Economic Review}

Vol. 3, No. 02; 2020

ISSN: 2581-4664

contribution of mobile money services to SMEs internationalization which was the main objective of this study.

Kimenyi and Ndung'u (2009) conducted a study on expanding the financial service frontier: the focus being lessons from mobile phone banking in Kenya. The study found out that the rapid growth in mobile money in Kenya is attributed to four factors: These factors are a conducive legal and tax environment, private-public policy dialogue, strategic and prudent macroeconomic policies, and a guarantee of the existence of a contestable market discouraging dominance by initial entrants. However, the study did not indicate whether this may lead to SMEs internationalization or not.

Abdelghani and Aziz (2014) conducted an empirical survey on the prospects of mobile money in Morocco;. The main purpose of the study was to examine the intention of the Moroccan customers to adopt mobile money, as well as the factors that may lead to it. The study employed a descriptive statistics, one sample t-test and multiple regressions. 400 questionnaires were randomly distributed to the Moroccan banks' customers. The findings indicated that the Moroccan customers have the willingness to adopt mobile money. Furthermore, the findings revealed that complexity, relative advantage, compatibility, and trial ability are good predictors of the intention to adopt mobile money in Morocco. However, it was not indicated whether this adoption may lead SMEs internationalization or not.

\section{Tanzania Related Studies}

Camner and Sjöblom (2009) compared the adoption of M-PESA in Tanzania to adoption in Kenya. They found much lower adoption rates in Tanzania, which was explained by the lower mobile telephony market share of Vodacom, who started the first M-PESA provider in Tanzania, its inability to build a strong agent network, and its lower marketing budget. They also mentioned other factors like Tanzania's generally lower GDP growth, smaller proportion of unbanked population, higher financial illiteracy, more dispersed population and the absence of a national ID. The study focused on the adoption rates and ignored the contribution of mobile money to SMEs internationalization. Di Castri and Gidvani (2014) conducted a study on enabling mobile money policies in Tanzania: The study focused on 'test and learn' approach to enabling market-led digital financial services. They found out that the Bank of Tanzania has taken a "test and learn" approach to enable MNOs to provide mobile money services, providing the industry regulatory guidance through the prudential and market conduct requirements listed in the "letters of no objection" released to authorize the MNOs and their partner banks to provide these new services. However, the study did not show whether or not the market-led digital financial services can lead to SMEs internationalization. Therefore, this study aims at accessed the contribution of mobile money services to SMEs internationalization to fill that knowledgeable gap.

Bångens and Söderberg (2011) conducted a study on mobile money transfers and usage among micro- and small businesses in Tanzania-Implications for policy and practice. The study specifically focused on business usage, such as paying suppliers or receiving payments from customers and paid less attention to person-to-person money transfer. The rationale for undertaking such a study was the lack of reporting on the phenomenon in existing literature apart from subjective evidence. The results were based on a non-randomized sample of 110 MSEs mainly located in Dar es Salaam, but partly in Morogoro, Singida, and Mwanza. 


\section{International Journal of Business Management and Economic Review}

Vol. 3, No. 02; 2020

ISSN: 2581-4664

The key findings were that MMT use is high (24\% for business use and an additional 15\% for personal use), actually double compared to the national average; the impact was mainly seen in time saved and improved logistics though there were indirect effects on liquidity, and SMEs are not happy with bank services which made the switch to mobile money easy. The other findings were that the size and frequency of transactions differ from the person-to-person market. Volumes were found to be much higher, sometimes reaching the ceiling amounts set by BoT, and sending /receiving as often as 2-3 times a week. It was also found out that SMEs' engaging in mobile money transfer show certain characteristics such as long-term business relationships that build trust, geographically separated from the buyer/seller, goods fairly standardized, and amounts transferred in the medium range (i.e. 300,000- 400,000 Tshs). This study did not explain whether or not such usages can lead to SMEs internationalization which was the general objective of this study.

Masamila (2014) conducted a study on the state of mobile money banking in Tanzania and security issues. The study found out that many consumers in Tanzania have mobile phones, but not bank accounts. Therefore, the mobile channel presents an effective way to connect them to the national financial grid. According to the findings for the local banks, going mobile may increase E-banks opportunities to unlock the inherent potential of under banked segments. This study addressed the current state, future prospects, and security challenges to the usage of mobile banking in Tanzania. The use of mobile money has increased security in financial services. The focus of this study was to link mobile money services and SMEs internationalization.

Anthony and Mutalemwa (2014) conducted a study on the factors influencing the use of mobile pin Tanzania the core focus being insights from Zantel's Z-pesa services. The findings revealed that there were several factors that hinder the adoption and usage of Z-pesa service: perceived ease of use, perceived usefulness, perceived cost, perceived mobility, perceived trust and perceived expressiveness. The study concluded with recommendations to address the challenges facing the adoption and usage of Z-pesa service. Despite these factors, this study sought to find out if they may lead to SMEs internationalization.

Nyamtiga., et al (2012) conducted a study on enhanced security model for mobile banking systems in Tanzania. The study found out that features for data encryption, integrity, secure entry of security details on the phone, and improved security policies in the application server are incorporated. They addressed issues of data confidentiality, user authentication and message integrity in order to provide end-to-end security of data carried on GSM networks. This study therefore, sought to understand how these security issues lead to SMEs internationalization.

\section{Conceptual framework of the Study}

The figure below provides the conceptual framework for the study. 
Vol. 3, No. 02; 2020

Independent Variables

(Mobile Money Services)
Dependent Variable

(SME's Internationalization)

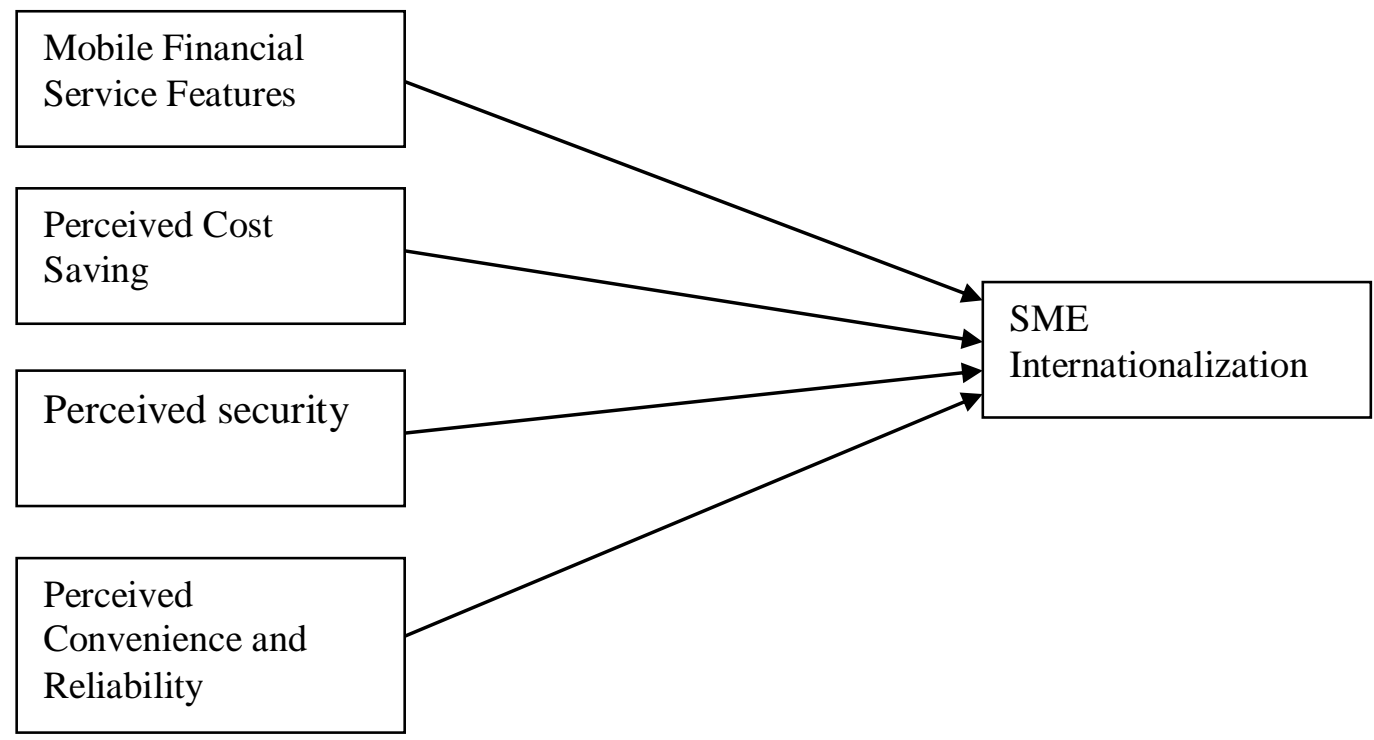

Source: Own developed model, (2019)

The figure above represents the research model with the one dependent variable and five independent variables. The dependent variable is SMEs internationalization while the independent variables are financial transactions, employment/income generation, money safety, money saving and convenience. The independent variables are benefits of mobile money banking and transactions which altogether foster SMEs internationalization. This is a comparative study which compared between mobile money banking/transactions and SMEs internationalization. Therefore, the study used positivism research design.

Quantitative and qualitative data were collected. The key informants open ended questionnaire was used to gather data from EPZA top management which provided useful mechanisms for increasing the content validity of numerical variables obtained from open ended questions.

A representative sample of 150 respondents was drawn from the population as indicated in Table 3.1 below. Purposive sampling was used to select respondents from EPZA management, while random sampling was used to select respondents from among SMEs actors and agents. 
Vol. 3, No. 02; 2020

ISSN: 2581-4664

\section{Sample Size}

\begin{tabular}{|l|l|l|l|l|l|l|}
\hline $\begin{array}{l}\text { Type } \\
\text { Respondents }\end{array}$ & $\begin{array}{l}\text { of } \\
\text { Type of Mobile Networks and expected } \\
\text { respondents }\end{array}$ & $\begin{array}{l}\text { No. of } \\
\text { Respon } \\
\text { dents }\end{array}$ & \\
\cline { 2 - 7 } & AIRTEL & VODACOM & TIGO & ZANTEL & $\begin{array}{l}\text { Sub } \\
\text { Total }\end{array}$ & $\begin{array}{l}\text { Grand } \\
\text { Total. }\end{array}$ \\
\hline Agents & 10 & 25 & 16 & 2 & 53 & 53 \\
\hline SMEs actors & 25 & 41 & 25 & 1 & 92 & 92 \\
\hline TOTAL & 35 & 66 & 41 & 3 & 145 & 145 \\
\hline $\begin{array}{l}\text { EPZA } \\
\text { MANAGEMENT }\end{array}$ & - & - & - & - & 5 & 5 \\
\hline GRAND TOTAL & 35 & 66 & 41 & 3 & 5 & 150 \\
\hline
\end{tabular}

Source: Field Data, (2019)

Primary data were obtained from the respondents who were mainly SMEs, mobile money agents and EPZA management.

Primary data were collected through a self-administered questionnaire to 145 respondents Agents and SMEs actors. Interview guide was developed to gather data from 5 key informants' i.e the top management of EPZA.

Secondary data for this study was obtained from secondary sources of information, including relevant national policies, journals, published thesis, dissertations magazines, books and the use of Internet.

In order to ensure the validity of the data collected and the data collection instruments, efforts were made to supplement quantitative data with qualitative data so as to minimize biasness and distortions. Whenever possible, the data gathered from the study area were checked to other possible sources. This helped to improve the level of validity and accuracy of data.

The Cronbach alpha, which is the coefficient of internal consistency was used as an estimate of the reliability and was used to measure the reliability of the study.

SPSS software was used to perform a descriptive analysis including the use of means, frequency, percentages, and standard deviation and tabulation. In order to identify outlier's, raw data was crosschecked ad transformation performed. In measuring SMEs perception and attitude in mobile banking, the Likert scale model was used

\section{RESULTS AND DISCUSSION}

The extent to which use of various mobile money services influences internationalization of SMEs can be established by way of looking how the technology of mobile money has made it easy for SMEs to conduct cross-border transactions in terms of removing geographical barriers. SMEs in Tanzania can simply exchange, commodities and money from its customers outside the country through use of mobile money services. Use of mobile money services has helped SMEs 


\section{International Journal of Business Management and Economic Review}

Vol. 3, No. 02; 2020

ISSN: 2581-4664

save time, minimize operational cost, increase convenience and reliability, access to financial services, and at the same time ensuring security in terms of safety and theft. Usefulness of mobile money services in influencing SMEs internationalization gains support from technological acceptance on the theory discussed in chapter two (Davis,1989). Also, a study by Nyaga (2014) on the impact of mobile money services on the performance of small and medium enterprises in an urban town in Kenya, reveal the same.

The first objective was to establish the extent to which financial services features conducted through mobile money relates to SME internationalization. The findings are presented, analysed and discussed in the context of sending and receiving money through mobile money service, the promptness of delivery through the use of electronic mobile money services, accessibility of mobile money services and financial services feature conducted through mobile money. The objective was to establish the extent to which these financial service features influence SMEs internationalization.

\section{Mean and Standard Deviation for Financial Service features of Mobile Money}

The financial service features of mobile money services influences SMEs internationalization positively because it is easily accessible through a mobile phone and speed of delivery is higher as compared to other means. However for the case of international transaction, it is not very efficient because of poor network infrastructure which is not reliable enough to support international connectivity. The study by Inter Media, (2012) cited the challenge of network infrastructure as an obstacle to the use of mobile money services in Uganda although did not refer cross-border transaction. Therefore since the financial service feature depends on strength of network infrastructure it is important to improve the network.

Linear regression model is used to present the analysis on the extent to which the dependent variable is affected by the independent variables. The mean and standard deviations are used to draw conclusion based on the findings in the table below

Mean and Standard Deviation for Financial Service Features of Mobile Money

\begin{tabular}{|l|l|l|l|}
\hline & $\mathrm{N}$ & Mean & Std. Deviation \\
\hline $\begin{array}{l}\text { Sending and receiving of mobile money } \\
\text { influence SMEs internationalization }\end{array}$ & 145 & 1.5310 & .73650 \\
\hline $\begin{array}{l}\text { Promptness of delivery of mobile money } \\
\text { service } \begin{array}{l}\text { influence SMEs } \\
\text { internationalization }\end{array}\end{array}$ & 145 & 1.6138 & .54245 \\
\hline $\begin{array}{l}\text { Accessibility of mobile money services } \\
\text { influence SMEs internationalization }\end{array}$ & 145 & 1.5793 & .64193 \\
\hline $\begin{array}{l}\text { Financial service features conducted } \\
\text { through mobile money influence SMEs } \\
\text { internationalization }\end{array}$ & 145 & 1.8000 & .52175 \\
\hline
\end{tabular}


International Journal of Business Management and Economic Review

Vol. 3, No. 02; 2020

ISSN: 2581-4664

\begin{tabular}{|l|l|l|l|}
\hline & $\mathrm{N}$ & Mean & Std. Deviation \\
\hline $\begin{array}{l}\text { Sending and receiving of mobile money } \\
\text { influence SMEs internationalization }\end{array}$ & 145 & 1.5310 & .73650 \\
\hline $\begin{array}{l}\text { Promptness of delivery of mobile money } \\
\text { service influence SMEs } \\
\text { internationalization }\end{array}$ & 145 & 1.6138 & .54245 \\
\hline $\begin{array}{l}\text { Accessibility of mobile money services } \\
\text { influence SMEs internationalization }\end{array}$ & 145 & 1.5793 & .64193 \\
\hline $\begin{array}{l}\text { Financial service features conducted } \\
\text { through mobile money influence SMEs } \\
\text { internationalization }\end{array}$ & 145 & 1.8000 & .52175 \\
\hline Valid N (list wise) & 145 & & \\
\hline
\end{tabular}

Source: Field Data, (2019).

The mean score of all the variables under this objective is $<3$ implying that financial service features of mobile money influences SMEs internationalization. Sending and receiving feature of mobile money have the highest standard deviation score of .73650 which indicates there is variability of the opinion. The mean and standard deviation shows that there is a substantial relationship between the dependent and the independent variables since the mean is $<3$ and the standard deviation is $>3$ which shows a greater variability of the sample. The findings provide that nearly all respondents gave same opinions about financial service features, promptness of delivery, accessibility of the mobile money services and SMEs internationalization. The findings correspond to a study by Anurag, et al., (2009), who found out that SMEs view this mode of payment as an easier form of cash delivery to their suppliers and business partners, a system which is relatively affordable, personal and can be used anywhere and at any time. These findings also confirm the response from key informants. All 5 respondents from EPZA agreed that mobile money services can influence SMEs internationalize. They admitted that most SMEs are highly constrained with capital therefore since the mobile money services are cheap and affordable will help SMEs who at the moment incur a lot of money to do cross border transactions. Also the findings are in line with Bagana \& Muturi, (2015) who conducted a study on factors affecting the uptake of MMT services by Micro and Small Enterprises in Pokot Central Sub-County. It was found that although the risk of sending money to the wrong telephone number is real, the same has not discouraged uptake of MMT service whereby the information on the transfer made can be retrieved and the money received back.

The second objective of the study was to determine the extent to which costs saving through mobile money services use relate to SME Internationalization. The findings are presented, 


\section{International Journal of Business Management and Economic Review}

Vol. 3, No. 02; 2020

ISSN: 2581-4664

analysed and discussed in the context of exchange rates on cross-border transactions. This took a closer look on the challenges associated with use of a foreign currency and lack of foreign exchange fee transparency. The analysis and discussion were also be based on differences of interest rate charged on securing finances for cross-border transactions and finally the affordability, and cost saving through use of mobile money services. Objective was to establish the extent to which cost saving through mobile money services use influences SMEs internationalization.

\section{Mean and Standard Deviation for Cost Saving through Mobile Money Services}

The table below represents the mean and standard deviation for objective two. The scores are meant to show results on how the dependent variable is affected by the independent variables, and the standard deviation to indicate the variability of opinion. The majority of the respondents positively agreed that perceived cost influence SMEs internationalization.

Mean and Standard Deviation for Cost Saving through Mobile Money

\begin{tabular}{|l|l|l|l|}
\hline & $\mathrm{N}$ & Mean & Std. Deviation \\
\hline $\begin{array}{l}\text { Exchange rates on cross-border } \\
\text { transactions }\end{array}$ & 145 & 1.4414 & .57586 \\
\hline $\begin{array}{l}\text { Interest rates through mobile money } \\
\text { influence SMEs internalization }\end{array}$ & 145 & 1.5724 & .60947 \\
\hline $\begin{array}{l}\text { Affordability of the use of mobile money } \\
\text { influence SMEs internationalization }\end{array}$ & 145 & 1.5724 & .58624 \\
\hline $\begin{array}{l}\text { Cost saving through mobile money } \\
\text { services influences SMEs } \\
\text { internationalization }\end{array}$ & 145 & 1.5862 & .57235 \\
\hline Valid N (list wise) & 145 & & \\
\hline
\end{tabular}

Source: Field Data, (2019).

The mean score average of the variables is $<3$ while interest rate has the highest score of .60 standard deviation. This implies that high interest rate charged by financial institutions to SMEs when they secure funds affect SMEs efforts to internationalize. To SMEs, interest rate means cost, therefore, when cost of financing business is on the high side it affects profitability. However, results show that there is a reasonable relationship between the dependent variable and 


\section{International Journal of Business Management and Economic Review}

Vol. 3, No. 02; 2020

ISSN: 2581-4664

the independent variables because the mean score is mean is <3. Results also indicate that standard deviation score is $>3$ suggesting that there is greater variability of the sample. Results in the table indicate that nearly all respondents provided more or less same opinions about exchange rates on cross-border transactions, interest rate, affordability of the use of mobile money and SMEs internationalization. The findings correspond to responses from EPZA informants. All respondents were also positive since they recommended mobile money saying it was a cheap and affordable means and easily accessible to SMEs regardless of their location. One respondent argued that some of the SMEs especially those operating in interior rural villages cannot easily access the bank services because of physical infrastructure challenge. Therefore, the use of mobile money services could be the best option.

The aim of the study was to determine the extent to which perceived security in mobile phone use relates to SMEs Internationalization. The findings are presented, analysed and discussed in the context of information security in mobile money services, Mobile money service as safe way of paying for cross-border transactions and discuss the aspect of fraud and internet hackers. The empirical studies discussed back in chapter two by Nyamtiga et al., (2012) are in support of the information security. The aspect of safety of mobile money service is cited back from empirical study by Anthony and Mutalemwa (2014) in chapter two. However, the objective was to establish the extent to which perceived mobile money service security influences SMEs internationalization.

\section{Mean and Standard Deviation for the Objective Perceived Mobile Money Service Security}

The mean and standard deviations are used to draw conclusion based on findings for the third objective. The scores are meant to show results on how the dependent variable is affected by the independent variables. The table below illustrates the findings of the study. 
Vol. 3, No. 02; 2020

ISSN: 2581-4664

\begin{tabular}{|c|c|c|c|}
\hline & $\mathrm{N}$ & Mean & Std. Deviation \\
\hline $\begin{array}{l}\text { Information security in mobile } \\
\text { money services lead to SMEs } \\
\text { internationalization }\end{array}$ & 145 & 1.6000 & .53229 \\
\hline $\begin{array}{l}\text { Mobile money is a safe way of } \\
\text { paying for a transaction in a foreign } \\
\text { market }\end{array}$ & 145 & 1.8897 & 1.17330 \\
\hline $\begin{array}{l}\text { Growing fraud cases and internet } \\
\text { hackers is a threat to SMEs seeking } \\
\text { to internationalize }\end{array}$ & 145 & 1.5034 & .70832 \\
\hline $\begin{array}{l}\text { Perceived mobile money } \\
\text { security influence } \\
\text { internationalization }\end{array}$ & 145 & 1.6207 & .54095 \\
\hline Valid N (list wise) & 145 & & \\
\hline
\end{tabular}

Source: Field Data, (2019).

According to (Maziriri \& Chuchu, 2017), the concept of risk is organized around the idea that consumer behavior involves risk in the sense that any consumer action will produce consequences that they cannot anticipate with anything approaching certainty. Results in the table above indicate that the mean score of the variable is $<3$, which implies that there is a reasonable relationship between the dependent variable and the independent variables. On the other hand safety on use of mobile money service scored the highest standard deviation of 1.17. This score denotes that perceived safety is a strong independent variable which affects SMEs internationalization than other variables. Results also show that standard deviation score is $<3$, since the mean score is $<3$, this indicates that there is greater variability of the sample which implies variability in respondent's opinions with regard to information security in mobile money services, mobile money safety, threat of fraud activities and SMEs internationalization. All respondents from EPZA had more or less same opinion about security on use of mobile money services. Although they positively recommended the service as a safe means, they highlighted a challenge of money laundering and the current issues of terrorism acts as a big threat to SMEs internationalization. The findings relate to that of Aldhmour (2016) who argued that, the degrees of risk that the consumers perceive and their ability to tolerate it are regarded as attitudinal factors that affect their technology use behaviors. 


\section{International Journal of Business Management and Economic Review}

Vol. 3, No. 02; 2020

ISSN: 2581-4664

The fourth objective of this study was to find out the extent to which convenience in the use of mobile money service influences SMEs internationalization. Presentation, analysis and discussion of the findings are done in the perspective of convenience of mobile money service. Time saved by SMEs, and simplicity in conducting international transactions.

\section{Mean and Standard Deviation for Reliability and Convenience through use of Mobile Money Services}

The table below shows the mean and standard deviation with regard to reliability and convenience through use of mobile money services and SMEs internationalization.

Mean and Standard Deviation for Reliability and Convenience Through use of Mobile Money Services

\begin{tabular}{|l|l|l|l|}
\hline & $\mathrm{N}$ & Mean & Std. Deviation \\
\hline $\begin{array}{l}\text { Convenience of mobile money } \\
\text { service lead to SMEs } \\
\text { internationalization }\end{array}$ & 145 & 1.6069 & .61573 \\
\hline $\begin{array}{l}\text { Time saved in conducting } \\
\text { international transactions through } \\
\text { mobile money services lead to } \\
\text { SMEs internationalization }\end{array}$ & 145 & 1.6621 & .47464 \\
\hline $\begin{array}{l}\text { Ease of use of mobile money } \\
\text { services lead to SMEs } \\
\text { internationalization }\end{array}$ & 145 & 1.6621 & .51668 \\
\hline $\begin{array}{l}\text { Reliability and convenience through } \\
\text { use of mobile money services } \\
\text { influence SMEs internationalization }\end{array}$ & 145 & 1.6345 & .48324 \\
\hline \begin{tabular}{l} 
Valid N (list wise) \\
\hline
\end{tabular} & 145 & & \\
\hline
\end{tabular}

Source: Field Data, (2019).

The mean score of the variables is $<3$ while convenience has highest standard deviation score of .61 which means that convenience of mobile money service has great influence to SMEs internationalization. Convenience means ease of accessibility of a particular service which helps to save money, time, and energy while increasing productivity. The mean and standard deviation further show that there is a corresponding relationship between the dependent variable and the independent variables since standard deviation score is $>3$ because the mean score is $<3$. The results of the study suggest that there is greater variability of the sample. Results in the table indicate that nearly all respondents provided more or less same opinions about convenience, time saved, reliability of using mobile money services and SMEs internationalization. The findings 


\section{International Journal of Business Management and Economic Review}

Vol. 3, No. 02; 2020

ISSN: 2581-4664

correspond to a study by Anuradi, at al., (2009). They revealed that the micro-business operators are able to transact payments directly with their customers and suppliers through a mobile phone in the palm of their hands without necessarily going through a bank and without having to leave their business premises. This is beneficial because all it requires is for one to have a mobile phone and basic literacy to operate the phone.

\section{CONCLUSIONS}

This study found out that the contribution of Mobile money services in facilitating cross border transactions in Tanzania is not enough to support SMEs internationalization. The study has identified several problems related to financial service features such as process and procedures which are exposed to money loss, the promptness/ speed of delivery and accessibility of the services. Another problem relates to costs incurred by SMEs Tanzania in the course of doing cross-border transactions, especially on exchange rate and interest rate and the affordability of SMEs to pay for the alternative services. A problem related to security is another area of concern. This relate to issues of information security, safety of the service and threat of hackers and cyber crooks. There are also problems related to reliability and convenience of the service like the ease/user-friendliness, time/appropriateness. This is caused by the technological nature of the service. The study found out that the use of mobile money services relative to SMEs internationalization in Tanzania was not encouraging. Readiness of the Mobile network operators (MNOs) who are the key stakeholders in providing the mobile money service, support of government to SMEs sector and the country's readiness to invest in telecom technology are among the major setbacks to expansion of mobile money services across borders.

There are numerous factors known to affect SMEs internationalization in Tanzania. The factors include among others the availability of funds, management attitudes, and knowledge of the market foreign market environment, risk perception, international networks and the intensity of competition. However, the need to adapt to the changing market and technological conditions in the regional and global economy cannot be over emphasized. The findings of this study clearly indicate there is a need for improving Mobile Money services to ensure they facilitate SMEs to conduct cross-border transactions. SMEs are more likely to internationalize their operations both through the formulation of a new strategy taking into account the information and communication technologies (Beneki et al., 2011). Globalization is increasing the importance of cross-border technologies which help to upgrade SMEs competitiveness and stimulate its growth (OECD, 2010). SMEs with greater ability need not only to integrate the internet technologies into enterprise resource management and customer relationship management but also to formulate an explicit strategy for the adoption and use of ICT. SMEs have potential to extend their activities on an international level. It is important that the government needs to support the Mobile Network Operators (MNOs) and the SMEs by creating enabling environment for investment in mobile money technology.

\section{RECOMMENDATIONS}




\section{International Journal of Business Management and Economic Review}

Vol. 3, No. 02; 2020

ISSN: 2581-4664

Based on the findings of this study, a number of recommendations are given. Financial service features of mobile money services have made it be easily accessible through a mobile phone and speed of delivery is high as compared to other means. Therefore the findings of this study recommend the use of mobile money for international transaction. The government and MNOs are advised to build network infrastructure reliable enough to support international connectivity. The study by (InterMedia, 2012) cited the challenge of network infrastructure as an obstacle to the use of mobile money services in Uganda although did not refer cross-border transaction. Since financial service feature depend on strength of network infrastructure, it is important that MNOs in Tanzania should be encouraged to work together with other stake holders from outside Tanzania, to integrate the mobile money systems in order to allow SMEs accessibility to use of this cheap and affordable means of money transfer.

Government must emphasize investment in the ICT sector through building enabling environment to attract FDIs from foreign high-tech and mobile companies in the country. By allowing more MNOs, competition will grow to enable SMEs easily access of cross-border mobile money services at low cost.

This study has revealed that mobile money systems are vulnerable to attacks and there are security threats which need mechanisms to protect SMEs against the threats and attacks. Moreover, TCRA should work in collaboration with other countries regulatory bodies, BoT, stakeholders among MNOs and other state organs to ensure SMEs are guaranteed on the security and confidentiality of the data upon doing cross border money transfers using mobile money services.

The findings of the study have proved the reliability and convenience of the use of mobile money services. The government through the Ministry of Communication is therefore encouraged to increase investment in building necessary infrastructures throughout the country so that MNOs can extend mobile money services even in rural areas. They should work together with mobile service providers (MNOs) to improve the micro business operators' use of the mobile payments and the digital technology by integrating the mobile money services with other operators cross border to allow the interoperability. This will enable the SMEs to transact larger payments. They should provide network infrastructure that minimizes congestion periods within the mobile network and enhance security measures. Transaction amounts from the existing low minimum should also be increased with cross border payments to larger amounts so as to enable SMEs to use the mobile service for larger payments. These measures would encourage a positive attitude in the mobile payment users which would result in increased use of the services.

The latest development in East Africa has seen MTN and Airtel mobile operators in Uganda, Rwanda and Kenya fast tracking to integrate mobile services to facilitate cross-border trasnfers. According to the two telecom companies, infrastructure to facilitate the service is ready. However, they say there have been delays in getting necessary regulatory approvals by the central banks in Rwanda, Kenya and Uganda. The same integration is happening in Malawi, where Airtel has announced the launch of cross border mobile money transfers. Vodacom Mpesa and Safaricom in Tanzania and Kenya have already launched cross-border transfers between the two countries.

Areas for further Studies 


\section{International Journal of Business Management and Economic Review}

Vol. 3, No. 02; 2020

ISSN: 2581-4664

This study focused on the contribution of mobile money services and SMEs Internationalization in Tanzania. Further studies can discuss the contribution of mobile money transfer service on household well-being. As this technology is still new to developing countries, a study can be conducted to assess the impact of mobile money transfer services on technological change and penetration of technology to users in rural areas. Another study can assess the challenges of the use of mobile money transfer services on control for money laundering. Another study can be conducted on the effect of power problems and the way it has been hindering the broad growth of mobile money transfer services in Tanzania.

\section{REFERENCES}

Ahokangas, P., 1998. Internationalization and resources: An analysis of processes in Nordic SMSs. Doctoral dissertation. Universitas Wasaensis, Vaasa.

Anderson, J. (2010).M-banking in Developing Markets: Competitive and Regulatory Implications. info, Vol. 12(1), $18-25$.

Balkenhol, B. (2007).Access to Finance: The Place of Risk Sharing Mechanisms and Development, 31(1) 69-90.Communications Commission of Tanzania. (2011/2012) Quarterly Sector Statistics Report;

Biggs, T A, and Manju K.S. (2013) African SMES, networks, and Manufacturing performance, Journal of Banking \& Finance, Volume 30, Issue 11, November 2006, Pages 3043-3066

Bosire M, \& Kamau, M, (2014) Effect of Mobile Money Transactions on Financial Performance of Small and Medium Enterprises in Nakuru Central Business District; Research Journal of Finance and Accounting, ISSN 2222-1697 (Paper) ISSN 2222-2847, Vol.5, No.12, 2014

Buckley, P. J., Ghauri, P. N., 1993. Introduction and overview. In: Buckley, P. J., Ghauri, P. N. (Eds.), The internationalization of the firm: A reader. Academic Press, London, pp. ix-xxi.

Carland, J. C \& Carland J. W (1993). Proceedings of the International Council for Small Business, 217- 229. Brockhaus, R. H. (1991).

Coviello, N. E., Martin, K., 1999. Internationalization of service SMEs: An integrated Perspective from the engineering consulting sector. Journal of International Marketing 7 (4), $42-$ 66.

Coviello, N. E., \& McAuley, A. (1999) Internationalization and the smaller firm: A review of contemporary empirical research. Management International Review, 39(3), 223-256.

Davidson, N. and Leishman, P. (2011).Building a Network of Mobile Money Agents. Mobile money for the Unbanked, GSMA, UK. 12pp.

Davidson, N. and Penicaud C, (2011), State of the Industry: Results from the 2011 Global Mobile Money Adoption Survey, GSMA, London

De Gournay, C. (2002). Mobile communication, private talk, Public Performance: Pretense of intimacy in France. In J. E. Katz \& M. Aarhus (Eds.), (pp. 193-205). Cambridge, UK: Cambridge University Press.

Desai RH, Herter T, Riccardi N, Rorden C, Fridriksson J. (2011).Concepts within Reach: Action Predicts action Language 224. doi: Processing in Stroke. Neuropsychologia 71, 217

Donovan, K. (2011). Mobile Money in Developing World: The Impact of M-Pesa on Development, Freedom and Domination (Prepublication Version) 


\section{International Journal of Business Management and Economic Review}

Vol. 3, No. 02; 2020

ISSN: 2581-4664

Donner, J. and Escobari, M. . A review of evidence on mobile use by micro and small Enterprises in developing countries. Journal of International Development. 22(5): 2010. 641658

Dunning, J. H. (1981). The eclectic paradigm of international production: A restatement and some possible extensions. Journal of International Business Studies, 19(1): 1-31.

Dunning, J. H. 1977. Trade, Location of Economic Activity and the Multinational Enterprise: A search for an eclectic approach.

Hesselborn, \& P. M. Wijkman (Eds.). The International Allocation of Economic Activity: 395418. London: Macmillan.

Gray, C.F (2005); Project Management: The Managerial Process, $5^{\text {th }}$ Edition McGraw-Hill/Irwin ISBN 0077426924, 9780077426927

Harris A, Goodman S, and Traynor P, (2013); Privacy and Security Concerns Associated with Mobile Money Applications in Africa Washington Journal of law, Technology \& Arts. Vol. 8, issue 3 Mobile Money Symposium

Herzberg, F.I. (2003), "One more time: How do you motivate employees. Harvard Business Review, Sep/Oct. 87, Vol. 65 Issue 5, p109-120.

Hegge, B. (2002), SMEs and European Integration: International Strategies Harvard Business Review, Sep/Oct. 87, Vol. 65 Issue 5, p109-120.

Hughes, N \& Lonnie. S (2007). M-Pesa: Mobile Money for the "Unbanked", Turning Cell Phones into 24-hour Tellers in Tanzania.

Jack, W. \& Suri, T. (2011). Risk Sharing and Transactions Costs: Evidence from Tanzania's Mobile Money Revolution Working Paper. The Journal of Language, Technology\& Entrepreneurship in Africa (JOLTE), Vol. 5no.2 2014

Jack, W. and Tavneet, S. (2010). The Economics of M-Pesa MIT. George Town University, Washington, DC. 30pp

Jan Johanson and Jan-Erik Vahlne (1977) Journal of International Business Studies Vol. 8, No. 1, pp. 2332

Jenny, C.A. \& Isaac, M. (2010). "Mobile Phones and Economic Development in Africa", Journal of Economic Perspectives, Vol. 24 No.3, 207-232.

Kartz, J.E (1999) Machines that becomes Us; , The social Context of Personal Communication Technology. Transactional Publishers; New Brunswick, USA and London (UK).

Kartz , J. E. (2006). Magic in the air: Mobile communication and the transformation of social life. New Brunswick, NJ: Transaction Publishers.

Katz, J. E., \& Aakhus, M. (eds.) (2002). Perpetual contact: Mobile communication, private talk, public performance. New York, NY: Cambridge University Press.

Katz, J. E., \& Sugiyama, S. (2006). Mobile phones as fashion statements: Evidence from student surveys in the U.S. and Japan. New Media \& Society, 8(2), 321-337.

Kothari, C. R. (2006), Research Methodology, $2^{\text {nd }}$ Ed, New Age International (P) LTD, Delhi, India.

Kuivalainen, O, Saarenketo, S and Puumalainen, K (2008) "Linking knowledge and Internationalization in small and medium sized enterprises in the ICT sector" Journal of internationalization of Finnish information and communication technology (ICT) firms from the knowledge-based Perspective.Vol.28,No.9, 2008, Pp591-601.

Lindsay Meredith (2001) "Market Strategy, Marketing Management Information 


\section{International Journal of Business Management and Economic Review}

Vol. 3, No. 02; 2020

ISSN: 2581-4664

Systems"Journal of Business and Industrial Marketing. Applied Economics European Management Journal. Vol.18 No.6, 2001, pp.605-618.

Leung L. and Wei R. Uses and Gratification of the Cellular Phone; Journal of Journalism and Mass communication Quarterly. Vol. 32 No. 5. 2000 Pp 693 - 714

Liesch, P.W., \& Knight, G.A., 1999. "Information Internalization and Hurdle Rates in Small and Medium Enterprise Internationalization", Journal of International Business Studies, Vol. 30, No. 2, pp. 383-394.

Man, T. W. Y., Lau, T., Chan, K. F., (2002). The competitiveness of small and medium Enterprises: A conceptualization with focus on entrepreneurial competencies. Journal of Business Venturing 17 (2), 123-142

Mbiti, I., \& Weil, D. (2011). "The Impact of M-Pesa in Tanzania". NBER Working Paper Tanzania Financial Sector Deepening Insights (2012). Issue 04 - April 2012.

Mbiti, I., \& Weil, D. N. (2011). "The Impact of M-Pesa in Kenya". NBER Working Paper No. 17129. JELL No. E40, 016, 033.

Mbogo M, (2010). The Impact of Mobile Payments on the Success and Growth of MicroBusiness: The Journal of Language, Technology \& Entrepreneurship in Africa. Vol. 2. No.1. 2010, Pp. 33-46

McDougall (2004). "International Entrepreneurship: the intersection of two researches parts", Journal of Small Strategic Management Journal Business Management, Vol. 43(5). 902-909.

Mitgwe, B., (2006) "Theoretical Milestones in International Business: The Journey to International Entrepreneurship Theory", Journal of International Entrepreneurship.Vol. 4, 2006. pp. 5-25

Morawczynski, O. (2009). "Examining the Usage and Impact of Transformational Banking in Kenya." In Internationalization,Design and Global Development, ed. Nurgy Aykin, 495-504. Berlin: Springer

Mupemhil S, Duve R,( 2013). Factors Affecting the Internationalization of Manufacturing SMEs in Zimbabwe; Midlands State University, Gweru, Zimbabwe.

Must, B., \& Ludewig, K. (2010). Mobile Money: Cell Phone Banking In Developing Countries. 38 Policy Matters Journal, Spring 2010, 27-33.

Ndiwalana, A. and Popov O. (2008). Mobile Payments: A Comparison between Philippine and Ugandan Contexts. IST-Africa 2008. P. Cunningham and M. Cunningham. Namibia, IIMC.

Ndunge, K, \& Mutinda, J (2012). Mobile Money Services and Poverty Reduction: A Study of Women Groups in Rural Eastern Tanzania. Institute for Money, Technology and Financial Inclusion (IMTFI). Working Pp.2011-12.

Ngasongwa . J, (2003)Small and Medium Enterprise Policy, Tanzania, Ministry of Industry And Trade Dar Es Salaam, April 2003

Njenga, A. (2009). "Mobile Phone Banking: Usage Experiences in Tanzania", MBA thesis, Catholic University of Eastern Africa.

Okutoyi, E. (2013). Mobile Money Transfers in Tanzania close to Country's National Budget .Humanipo, Home to African transfers- Tanzania close Countrys-National- budget.

Olejnik, E, (2013). International Small and Medium-Sized Enterprises, Handel und International Wiesbaden F, 2014: Marketing / Retailing and International Marketing, DOI 10.1007/978-3-65804876-1_2

Oviatt, B. M., \& McDougall, P. P. (2005b). Toward a theory of international new Ventures. 


\section{International Journal of Business Management and Economic Review}

Vol. 3, No. 02; 2020

ISSN: 2581-4664

Journal of International Business Studies, 36(1): 29-41.

Oviatt, B. M., \& McDougall, P. P. (2005). Defining international entrepreneurship and modeling the speed of internationalization. Entrepreneurship Theory and Practice, 29(5): 537-554.

Papulova, E. and Papulova, Z. (2006) "Competitive strategy and competitive advantage of Small and midsized manufacturing enterprises in Slovakia" E- Leaders Practice. Pretoria: Unison Press. Richard, P.(2013); 10 Reasons to go International |Founder \& CEO| Atlantric LLc, Wash Schoolof Foreign Studies Georgetown University

Ruzzier M. \& Maja K. (2010), "The Internationalization Strategies of SMEs: The case of The Slovenian hotel industry

Rutashobya, L. \& Jaensson J E. (2004). "Small firms' internationalization for Development in Tanzania: Exploring the network phenomenon, International Journal of Social Economics, 31 (1/2), pp. 159-172.

Schindler, P. S. (2008). Business Research Methods. $10^{\text {th }}$ Edition; McGraw- Hill International Edition; Singapore.

Tobbin, P. E. (2010). Modeling Adoption of Mobile Money Transfer: A Consumer Behaviour Analysis Paper presented at The 2nd International Conference on Mobile Communication Technology for, Kampala, Uganda.Tanzania Communications Regulatory Authority (2013), The Regulator Quarterly Newsletter of the Tanzania Communications Regulatory board, No. 3, Tobbin, P. (2011). Adoption of mobile money transfer technology: Structural Equation Modeling Approach. European Journal of Business and Management, 3(7), 59-77

Vahlne, J. E. \& Johanson, J., (1977). The internationalization process of the firm: A Model of knowledge development and increasing foreign market Commitments: Journal of International Busines Studies, 8(4),23-32.

Westhead P, Wright, M., Ucbasaran, D., (2002). International market selection strategies by 'Micro' and 'small firms. The International Journal of Management Science 30, 51-68. Wambari, A., \&

Mwaura, P., (2009). "Mobile Banking in Developing Countries. (A case Study of Tanzania). Information Technology, Vaasan

Wei R. and Leung L. Uses and Gratification of the Cellular Phone; Journal of Journalism and Mass communication Quarterly. Vol.32 No. 5. $2000 . \quad$ Pp. 693 - 714

Wei, R., \& Leung, L. (1999). Blurring public and private behaviors in public space: Policy challenges in the use and improper use of the cell phone. Telematics and Informatics, 16, 11-26 Wishart, N. (2006). Micro-Payment Systems and Their Application to Mobile Networks. Washington, $D C$ :

Westhead, P., Wright, M., Ucbasaran, D. (2002), Internationalization of private firms: environmental turbulence and organizational strategies and Resources, Entrepreneurship \& Regional Development, 501-52 